Opinion

\section{Proposal for the elimination of allergies}

\section{James F Walles*}

Free Lance Writer, USA

A man I knew had an extreme allergy to poison ivy when he was a child. When he was about four-teen, he was hanging out with a group of his friends who dared him to eat some poison ivy. He did, and never got poison ivy again. Presumably, the ingestion of the allergen led to the development of immunity.

This might be a pathway to eliminating allergies-ingest the allergen. For example, cutting up poison ivy leaves into small pieces and crushing them with a mortar and pestle should lead to some juice in the mortar. Allow that to evaporate and have a test subject ingest the resultant powder, which, like pollen, etc., could be compressed into a pill. Wait 48 hours, and then see if the subject gets a rash when a small, unimportant area of the body is exposed to poison ivy leaves-and have Ivy-Dry handy. This could be a way to eliminate allergies-ingestion of the allergen.

\section{More Information}

Submitted: 25 June 2019

Approved: 10 July 2019

Published: 11 July 2019

How to cite this article: Welles JF, Proposal for the elimination of allergies. Insights Clin Cell Immunol. 2019; 3: 019-019.

https://doi.org.10.29328/journal.icci.1001010

Copyright: (c) 2019 Welles JF. This is an open access article distributed under the Creative Commons Attribution License, which permits unrestricted use, distribution, and reproduction in any medium, provided the original work is properly cited

ISSN: 2640-2793

Check for updates 